\title{
Олег ЖУк
}

\section{ФІНАНСОВИЙ МЕХАНІЗМ СИСТЕМИ СОЦІААЬНОГО ЗАХИСТУ НАСЕАЕННЯ УКРАЇНИ}

Проаналізовано та узагальнено погляди науковців щодо визначення сутності та структури фрінансового механізму системи соціального захисту населення. Запропоновано авторське визначення понять "соціальний захист", "фрінансовий механізм системи соціального захисту населення" та "фрінансове забезпечення соціального захисту населення". Подано авторську структуру вітчизняного фрінансового механізму системи соціального захисту населення, розроблено рекомендації щодо його вдосконалення в умовах реформування національної економіки.

Ключові слова: соціальний захист, фрінансовий механізм системи соціального захисту населення, фрінансове забезпечення соціального захисту населення, фрінансові методи, фрінансові інструменти, фрінансові важелі.

\section{Олег ЖУК}

Финансовый механизм системы социальной защиты населения Украины

Проанализированы и обобщены взгляды учёных относительно определения предмета и структуры фринансового механизма системы социальной защиты населения. Предложено авторское определение понятий "социальная защита", "финансовый механизм системы социальной защиты населения" и "фринансовое обеспечение социальной защиты населения". Представлена авторская структура отечественного фринансового механизма системы социальной защиты населения, разработаны рекомендации по его совершенствованию в условиях реформирования национальной экономики.

Ключевые слова: социальная защита, финансовый механизм системы социальной защиты населения, финансовое обеспечение социальной защиты населения, финансовые методы, фринансовые инструменты, фринансовые рычаги.

\section{Oleh ZHUK}

\section{Financial mechanism of people's social protection system in Ukraine}

Introduction. Implementation of effective and acting policy of people's social protection demands the creation of an appropriate financial mechanism of its realization that could be able to provide a significant welfare increasing of every citizen of Ukraine.

Purpose. The purpose of the article is to research theoretical, methodological, organizational and practical aspects of functioning the financial mechanism of people's social protection system in Ukraine and to develop recommendations for its improvement in terms of transfor-

С Олег Жук, 2017 
mation of the national economy, considering the current socio-economic and military-political situation in the country.

Results. The views of some authors to determine the nature and structure of the financial mechanism of people's social protection system in Ukraine are analyzed and summarized. The author suggests his own definition of the concepts of "social protection", "financial mechanism of people's social protection system" and "financial support of people's social protection". The structure of the domestic financial mechanism of people's social protection system that includes groups of four main elements (financial and organizational forms, financial methods, financial instruments and financial levers) are presented by the author.

Conclusion. Improving the financial mechanism of PSPS in Ukraine there should be achieving an effective and mutual cooperation and interaction of financial mechanisms of structural components of the social protection system: social insurance, social support, social standards and guarantees of the state to its population.

Keywords: social protection, financial mechanism of people's social protection system, financial support of people's social protection, financial methods, financial instruments, financial levers.

JEL Classification: H55, H75, I38.

Постановка проблеми. У статті 1 Конституції України проголошено: "Україна $є$ суверенна і незалежна, демократична, соціальна, правова держава". Тому проблеми гарантування та реалізації цих положень $є$ одними із найбільш актуальних стратегічних завдань нашої держави на сучасному етапі. Найважливішим серед них $є$ створення ефективної системи соціального захисту населення, яка не лише $€$ засобом наближення до міжнародних стандартів рівня життя, а й дієвим інструментом підтримки існуючого конституційного ладу, досягнення соціальної справедливості та злагоди у суспільстві. Водночас ефективність системи та рівень соціального захисту населення залежать від якісного фінансового забезпечення як невід'ємного структурного елемента фрінансового механізму. Відтак здійснення ефективної політики соціального захисту населення вимагає створення відповідного фрінансового механізму її реалізації, здатного забезпечити істотне підвищення добробуту кожного громадянина України.
Аналіз останніх досліджень і публікацій. В період численних змін у соціальноекономічному та політико-правовому житті нашої держави проблематика створення ефективного фрінансового механізму системи соціального захисту населення опинилась у центрі уваги науковців, політиків та громадськості. Зокрема, ця тема висвітлена у працях вчених-економістів Л. Баранник [1; 2] та Н. Савченко [3]. Науковці Л. Бабич [4], Л. Васечко [5], С. Горянська [6], І. Динь [7], Л. Клівіденко [8] здебільшого досліджують проблеми функціонування фрінансового механізму системи соціального захисту населення у конкретних ії̈ підсистемах (соціальному страхуванні, пенсійному забезпеченні тощо). Крім того, серед авторів існують деякі розбіжності у тлумаченні понять "соціальних захист" та "фрінансовий механізм системи соціального захисту населення", сутності та ролі окремих його структурних елементів. На державному рівні досі не розроблено науково обґрунтовану, побудовану на єдиних методологічних принципах, концепцію фрінансового забезпечення 
соціального захисту населення. Суттєвим недоліком $€$ відсутність економічної стратегії у соціальній сфері України, зволікання з прийняттям Пенсійного кодексу України. Відтак означена проблематика є досить актуальною для українського суспільства та потребує подальшого дослідження.

Метою статті $€$ дослідження теоретичних, методологічних та організаційнопрактичних аспектів функціонування фрінансового механізму системи соціального захисту населення України і розроблення рекомендацій щодо його вдосконалення в умовах реформування національної економіки, враховуючи існуючу соціально-економічну та воєнну-політичну ситуацію в країні.

Виклад основного матеріалу дослідження. Еволюція фрінансової системи призвела до виокремлення соціального захисту населення у відносно самостійну ії ланку, якій притаманний власний фінансовий механізм. Термін “фрінансовий механізм системи соціального захисту населення" зустрічається не часто, і лише в окремих працях розкривається його зміст. Проте в його трактуванні різними авторами існують певні розбіжності. Так, Н. Г. Савченко розглядає фінансовий механізм системи соціального захисту населення під "управлінським кутом зору" і визначає його як "систему управління фрінансовими відносинами через сукупність встановлених державою методів, інструментів і важелів з відповідним регулюванням та забезпеченням їх впливу на рівень соціального захисту населення" [3, с. 6].

Водночас у своєму дослідженні Л. Б. Баранник констатує, що називати фінансовий механізм системою не зовсім правильно, адже механізм, на думку дослідниці, - це внутрішня будова машини, устрою, апарату тощо, що призводить їх у дію, організовує і забезпечує функціонування. У нашому випадку - “запускає в дію" систему соціального захисту населення. Враховуючи цю обставину, дослідниця пропонує під фрінансовим механізмом системи соціального захисту населення розуміти "сукупність способів організації фрінансових відносин, що виникають під час формування і використання фінансових ресурсів 3 метою забезпечення умов для нормальної життєдіяльності людей, котрі потрапили у складні життєві обставини через дію соціальних ризиків" [1, с. 209].

Розглядаючи соціальний захист як складну багаторівневу систему, структура якої представлена соціальним страхуванням, соціальним забезпеченням та соціальними стандартами й гарантіями держави населенню, що комплексно взаємодіють, взаємодоповнюють один одного та сприяють ефективному функціонуванню механізму системи соціального захисту населення країни, вважаємо, що кожна 3 цих трьох структурних складових системи соціального захисту населення має власний особливий фрінансовий механізм реалізації. Відтак функціонування фрінансового механізму системи соціального захисту населення в цілому може бути ефективним за умов узгодженої взаємодії фрінансових механізмів її структурних складових. Відповідно до найбільш загальних позицій, термін "механізм" розглядаємо як сукупність складових (деталей) цілого (системи), які, взаємодіючи, служать для передачі та перетворення руху на кожному етапі й забезпечують рух системи у визначеному напрямку. На підставі викладеного пропонуємо розглядати фінансовий механізм системи соціального захисту населення у вузькому та широкому розуміннях. У широкому - це сукупність автономних фрінансових механізмів соціального страхування, соціального забезпечення та соціальних стандартів й гарантій, що комплексно взаємодіють, взаємодоповнюють один одного та сприяють ефективному 
його функціонуванню з метою забезпечення сталого розвитку держави та задоволення життєво необхідних потреб кожного громадянина на рівні не нижче прожиткового мінімуму.

Фінансовий механізм системи соціального захисту населення у вузькому розумінні - це певний комплекс спеціально розроблених, законодавчо закріплених та визначених соціально-економічною політикою форм і методів, інструментів і важелів акумулювання, перерозподілу і використання фінансових ресурсів з метою забезпечення добробуту кожного члена суспільства та підвищення рівня соціального захисту найбільш незахищених верств населення - осіб з обмеженими фізичними і розумовими можливостями, безробітних, багатодітних родин, дітей-сиріт та ін.

Більш ґрунтовно до структуризації фрінансового механізму системи соціального захисту населення, на нашу думку, підійшла Л. Б. Баранник, котра, деталізуючи структуру досліджуваного механізму, зазначає, це - "сукупність фрорм і методів, інструментів і важелів фрормування та використання фондів фрінансових ресурсів 3 метою захисту населення від соціальних ризиків" [1, с. 216]. Основні структурні елементи фрінансового механізму системи соціального захисту населення дослідниця згрупувала у такі три ланки, як організаційні фрорми (органи управління системою соціального захисту населення, правове, нормативне, інформаційне, технічне та кадрове забезпечення), методи (фрінансове планування, фрінансове забезпечення, фрінансове регулювання та фрінансовий контроль і облік) та важелі (фінансові ресурси, фінансові резерви, пільги, стимули, санкції, норми, ліміти, нормативи і квоти) [1, с. 212]. На особливу увагу також заслуговує і підхід Н. Г. Савченко. До структурних елементів фінансового механізму системи соціаль- ного захисту населення дослідниця відносить: організаційне забезпечення (головні суб'єкти управління - органи законодавчої та виконавчої влади); нормативно-правове регулювання соціально-економічної політики; інформаційне забезпечення; методи, інструменти та важелі [3, с. 6].

Враховуючи різні підходи дослідників до структуризації фрінансового механізму системи соціального захисту населення, пропонуємо власне бачення цієї структури (рис. 1). Вважаємо, що фрінансовий механізм системи соціального захисту населення має такі самі складові елементи, що властиві і загальному фрінансовому механізму. Однак роль кожного з цих елементів у системі соціального захисту населення набуває своєї специфіки, відтак вони відрізняються за ступенем складності та значимості. Специфічність фрінансового механізму системи соціального захисту населення випливає 3 того, що система соціального захисту населення $є$ системою грошових відносин та опосередковує процеси руху грошових потоків, які перетворюються потім на державні та приватногосподарські фрінансові ресурси і використовується для соціального захисту населення внаслідок дії спеціальних фрінансових методів. У структурі фрінансового механізму системи соціального захисту населення виокремлюємо чотири основні групи елементів: фрінансово-організаційні фрорми, фінансові методи, фрінансові інструменти та фінансові важелі. При цьому зазначимо, що останні дві групи є засобами фрінансового регулювання.

У науковій і навчальній літературі всі структурні елементи фрінансового механізму досить детально описані. Тому зупинимося лише на деяких, використання яких останнім часом набуло особливого значення та резонансу.

Як уже зазначалось, елементом фрінансового механізму системи соціального за- 
ДЕРЖАВНI I МІСЦЕВI ФIНАНСИ

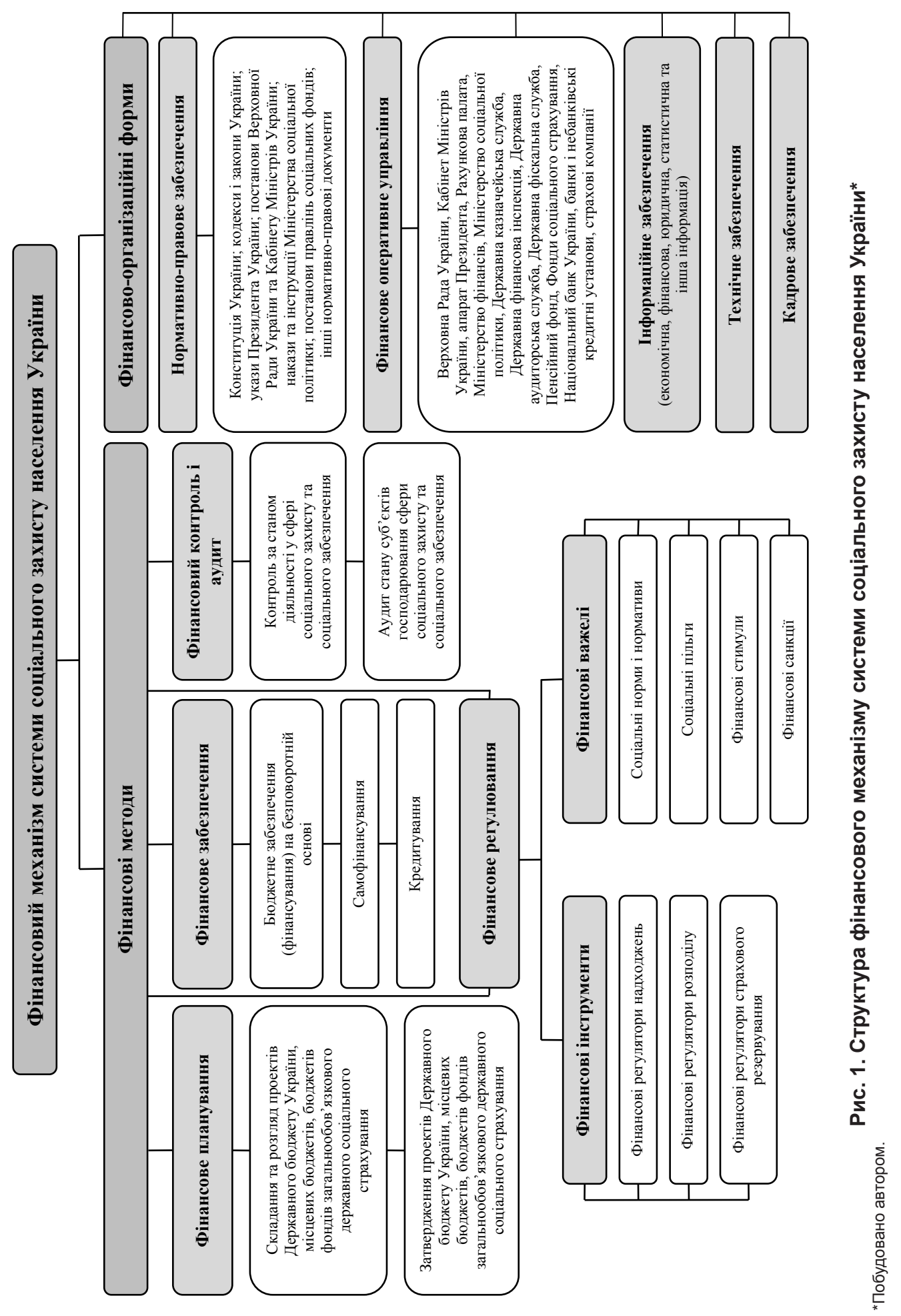


хисту населення $€$ фрінансово-організаційні форми: фрінансове оперативне управління, нормативно-правове, інформаційне, технічне та кадрове забезпечення.

Фінансове оперативне управління - це комплекс заходів, що розробляються на основі оперативного аналізу існуючої фрінансової ситуації та здійснюються відповідними інституціями згідно з чинним законодавством з метою регулювання, складання та виконання фінансових планів, а також здійснення дієвого поточного контролю за їх виконанням та своєчасним внесенням необхідних змін.

Для ефективного функціонування фрінансового механізму необхідним є його відповідне нормативно-правове забезпечення, представлене, передусім, Конституцією України, кодексами і законами України, указами Президента України, постановами Верховної Ради України та Кабінету Міністрів України, наказами та інструкціями Міністерства соціальної політики, постановами правлінь соціальних фондів та іншими нормативно-правовими документами.

Інформаційне забезпечення функціонування фінансового механізму системи соціального захисту населення складається 3 різного роду економічної, фрінансової, юридичної, статистичної та іншої інформації.

Технічне забезпечення передбачає забезпечення співробітників органів праці та соціального захисту населення технікою (насамперед комп'ютерною), бланковою документацією для раціонального забезпечення функціонування облікового, аналітичного та контрольного процесів (здійснення персоніфікова-ного обліку громадян, формування та ведення різного роду баз даних про громадян, котрі отримали чи мають право отримувати ті чи інші соціальні послуги у сфері соціального захисту).

У зв'язку зі зростанням останніми роками чисельності тих, хто потребує соці- ального захисту (вимушені переселенці, учасники антитерористичної операції та члени їхніх сімей, а також члени сімей загиблих учасників антитерористичної операції), особливого значення набуває кадрове забезпечення системи соціального захисту населення. Згідно з чинним законодавством соціальні служби покликані професійно надавати послуги населенню для вирішення життєво необхідних проблем.

Наступний елемент фрінансового механізму системи соціального захисту населення - це фінансові методи: фрінансове планування (прогнозування), фрінансове забезпечення, фрінансове регулювання та фінансовий контроль і аудит.

На стадії планування визначаються фрінансові можливості держави та інших суб'єктів господарювання щодо задоволення життєвих потреб усіх членів суспільства на засадах соціальної рівності та справедливості, надання необхідної соціальної допомоги найбільш незахищеним його членам. Фінансове планування застосовується на етапі розроблення бюджетних запитів, складання проекту кошторису витрат на утримання головного (районного) управління, визначення потреби населення певної території у різних видах соціальної допомоги та послуг.

Від початку складання фінансових планів до затвердження звітів про їх виконання 3 метою дотримання чинного фрінансовогосподарського законо-давства у процесі здійснення соціального захисту населення проводиться фрінансовий контроль, спрямований на перевірку правильності вартісного розподілу і перерозподілу валового внутрішнього продукту, цільового й ефективного використання коштів із відповідних фондів, порівняння фрінансових результатів від використання фрінансових ресурсів із плановими та виявлення резервів їх збільшення. 
Ефективність системи та рівень соціального захисту населення залежать від якісного фрінансового забезпечення. Загальноприйнятого визначення фрінансового забезпечення соціального захисту населення в науковій літературі не існує. В більшості наукових дослідженнях фінансове забезпечення розглядається в контексті фрінансового механізму, але по-різному позиціонується стосовно нього: як "метод", “структурна підсистема”, “елемент”, “фрункція”. Крім цього, існують й інші підходи: “сукупність цільових грошових фондів", "система грошових відносин розподільчого характеру”, “діяльність держави та інших юридичних осіб”, "рух фрінансових ресурсів", “фрункція фрінансів" та ін.

Спираючись на попередні теоретичні надбання українських учених і намагаючись їх узагальнити, виходячи із визначення загальнонаукової фрілософської суті таких категорій, як "метод”, “підсистема”, “елемент”, “функція”, вважаємо, що фрінансове забезпечення позиціонується відносно фрінансового механізму як метод. Термін “метод” походить від грецького "metodos”, що означає “шлях дослідження, теорія, вчення". Метод - це засіб досягнення будь-якої мети, вирішення конкретного завдання; сукупність прийомів або операцій практичного чи теоретичного засвоєння (пізнання) дійсності. Однак деякі науковці наголошують на тому, що називати фінансове забезпечення соціального захисту населення методом фрінансового механізму системи соціального захисту, який “визначає джерела та форми фрінансування соціального захисту 3 метою забезпечення високої якості життя населення" неправильно. Свою позицію науковці аргументують тим, що у наведеному визначенні “фрінансове забезпечення охоплює тільки соціальні фонди, тоді як соціальний захист здійснюється як за рахунок бюджетних, так і комерційних і благодійних коштів" [6; 8]. Враховуючи вищевикладене, пропонуємо розглядати фрінансове забезпечення соціального захисту населення як метод фінансового механізму системи соціального захисту населення, який визначає джерела, форми й інструменти фрінансування програм у сфері соціального захисту сім'ї, дітей, молоді, пенсіонерів, ветеранів, інвалідів, безробітних та інших соціально незахищених верств населення з метою забезпечення добробуту кожного члена суспільства в конкретних економічних умовах шляхом бюджетного фрінансування на безповоротній основі, самофінансування та кредитування, а також у деяких інших випадках - донорського фінансування.

Фінансове забезпечення та фінансове регулювання $€$ узагальнюючими методами фінансового механізму, оскільки охоплюють часткові методи фрінансового впливу на соціально-економічний розвиток суспільства. Вони тісно взаємопов'язані між собою й органічно доповнюють один одного. Фінансове забезпечення реалізується на основі встановлених систем фінансування, що здійснюється в таких трьох формах: бюджетне забезпечення (фінансування), самофінансування та кредитування. Кожна з цих форм має особливість практичного застосування. Наприклад, у випадку бюджетного фінансування враховуються умови визначення обсягів фрінансування, норми певних видів витрат, періодичність передання коштів тощо. Самофінансування передбачає розрахунок доцільності й ефективності витрачання власних коштів, визначення засобів їх мобілізації тощо. У разі кредитування визначаються умови надання кредитів, гарантії та терміни їх повернення, окупність та ефективність кредитів. Крім вищенаведених форм фрінансового забезпечення, також передбачено донорське фінансування, що здійснюється на безоплатній основі іноземними державами, урядами іноземних дер- 
жав, спеціальними міжнародними фондами та організаціями, як правило, у вигляді грантів у рамках міжнародної технічної або фінансової допомоги.

На нашу думку, фінансове забезпечення в Україні реалізується через три основні структурні складові системи соціального захисту населення: соціальне страхування, що базується на формуванні позабюджетних цільових фондів за рахунок внесків учасників; соціальне забезпечення, що передбачає виплату адресних соціальних допомог або послуг за рахунок загальнодержавних коштів, які акумулюються в бюджетах різних рівнів; соціальні стандарти й гарантії держави населенню, які встановлюються законами з метою забезпечення конституційного права громадян на достатній життєвий рівень.

Основними елементами фінансового регулювання $є$ оподаткування (вилучення частини доходів у юридичних і фізичних осіб до бюджетів різних рівнів і державних цільових фондів) та бюджетні трансферти (передання коштів з одного бюджету до іншого на безоплатних і безповоротних засадах у формі бюджетного субсидіювання чи вилучення бюджетного надлишку: дотації, субвенції, субсидії). Як уже зазначалося, засобами фінансового регулювання $€$ фінансові інструменти та важелі.

У своїх дослідженнях Н. Г. Савченко виокремлює дві групи інструментів фінансового механізму системи соціального захисту населення - фінансові регулятори надходжень і фрінансові регулятори розподілу. До першої групи дослідниця відносить: у рамках підсистеми соціального забезпечення - податки, збори, офіційні трансферти, кредити та ін.; у рамках підсистеми соціального страхування - страхові внески, бюджетні асигнування, прибуток, кошти, одержані від стягнення штрафів і пені, благодійні внески, банківські кредити та ін. Фінансовими регуляторами розподілу автор визначає: у рамках підсистеми соціального забезпечення - соціальні видатки, соціальні гарантії, соціальні трансферти, заробітна плата та ін.; у рамках підсистеми соціального страхування - страхові виплати, матеріальна допомога, дотації, відшкодування збитків і витрат; превентивні заходи та ін. [3, с. 9].

$\mathrm{He}$ заперечуючи вагомості цього дослідження, водночас поділяємо точку зору Л. М. Бабич щодо виокремлення третьої групи інструментів фінансового механізму системи соціального захисту населення фінансових регуляторів страхового резервування (резерви коштів відповідних фондів для поточних потреб; резерв коштів для покриття дефіциту бюджету Пенсійного фонду України; резерви страхових коштів для забезпечення фінансової стабільності страхових позабюджетних фондів, окрім Пенсійного фонду України) [4, с. 162].

Фінансові важелі як елемент фінансового механізму системи соціального захисту населення включають соціальні норми і нормативи, соціальні пільги, фрінансові стимули та санкції.

Виокремивши інструменти фінансового механізму системи соціального захисту населення, Н. Г. Савченко наголошує, що на добробут громадян країни впливають такі фінансові важелі: в рамках підсистеми соціального забезпечення - ставки податків, зборів, розміри оплати праці, соціальних трансфертів, фінансові показники прожиткового мінімуму, основних соціальних гарантій, державні нормативи видатків на охорону здоров'я, освіту тощо; у рамках підсистеми соціального страхування - розміри відрахувань, страхових внесків на соціальне страхування, розміри страхових виплат, матеріальних допомог, дотацій тощо [3, с. 9].

Висновки. На основі проведеного дослідження вважаємо, що розвиток прин- 
ципово нових форм фрінансових відносин та помітні зміни в соціальній структурі українського суспільства тягнуть за собою ускладнення фрінансового механізму. Врахувавши цей факт, головне призначення сучасного фінансового механізму системи соціального захисту населення полягає не лише у створенні реальної фінансової бази для реалізації соціальних проектів/програм, а й у здійсненні державного регулювання економіки в умовах реформування економіки України.

При цьому важливою складовою фінансового регулювання $€$ фінансові важелі, зокрема соціальні пільги. Діюча в Україні система пільг $є$ фрінансово необґрунтованою, значною мірою декларативною, непрозорою і соціально несправедливою. При цьому майже кожна третя особа в країні має статус пільговика, а їхня чисельність помітно зростає вже не з кожним роком, а з кожним місяцем. Так, зі значним підвищенням тарифів на житлово-комунальні послуги у черзі за статусом пільговика стоять не лише пенсіонери, а й відомі політики та бізнесмени. Реформувати цей напрям соціального захисту населення вкрай необхідно, але робити це, на нашу думку, потрібно зважено, поступово відмовляючись від пільг взагалі. Вони мають поступитися місцем соціальній допомозі як одній із основних форм соціального забезпечення населення. Одним із найбільш принципових питань у цьому контексті $€$ питання про перехід від патерналістської до адресної системи соціального захисту. Таким чином, створення ефективного фрінансового механізму системи соціального захисту населення дасть можливість надавати населенню адресні якісні соціальні послуги та здійснювати виплати законодавчо закріплених соціальних гарантій.

Удосконалення фінансового механізму системи соціального захисту населення
України має відбуватися при досягненні ефективної взаємодії та взаємовпливу фрінансових механізмів структурних складових системи соціального захисту: соціального страхування, соціального забезпечення, соціальних стандартів й гарантій держави населенню.

\section{Список використаних джерел}

1. Баранник Л.Б. Фінансовий механізм системи соціального захисту населення України: понятійно-сутнісна характеристика/Л.Б. Баранник// Вісник ЛДФА. - 2011. - № 21. - С. 208-218.

2. Баранник Л.Б. Фінансове забезпечення системи соціального захисту населення: теоретичний аспект / Л.Б. Баранник // ВіСник ДДФА. Економічні науки. - 2014. - № 1. C. 8-15.

3. Савченко Н.Г. Фінансовий механізм соціального захисту населення України : авторефр. дис. ... канд. екон. наук : спец. 08.00.08 “Гроші, фрінанси і кредит" / Н.Г. Савченко. - К. : КНТЕУ, 2010. - 19 c.

4. Бабич Л.м. Оптимізаційна модель фрінансового механізму соціального страхування України / Л.м. Бабич, Л.І. Васечко // Актуальні проблеми економіки. - 2009. - № 1. - С. 158-170.

5. Васечко Л.І. Фінансовий механізм соціального страхування в Україні : авторефр. дис. ... канд. екон. наук : спец. 08.00.08 “Гроші, фрінанси і кредит" / Л.І. Васечко. - Ірпінь. - 2010. - 23 с.

6. Горянська С.В. Фінансове забезпечення соціального захисту населення / С.В. Горянська // Фінанси України. - 2001. - № 6. - С. 87-95.

7. Динь І.М. Фінансовий механізм функціонування пенсійних фоондів в Україні : автореф. дис. ... канд. екон. наук : спец. 08.00.08 “Гроші, фонанси і кредит" / І.М. Динь. - Львів : ІРД НАН України, 2010. - 20 с.

8. Клівіденко Л.М. Фінансове забезпечення соціального захисту України: авторефр. дис. ... канд. екон. наук : спец. 08.04.01 “Фінанси, грошовий обіг і кредит" / Л.М. Клівіденко. - Тернопіль : THЕУ, 2006. - 20 с. 


\section{ДЕРЖАВНI I МІСЦЕВI ФІНАНСИ}

\section{References}

1. Barannyk, L.B. (2011). Finansovyi mekhanizm systemy sotsialnoho zakhystu naselennia Ukrainy: poniatiino-sutnisna kharakterystyka [The financial mechanism of people's social protection system in Ukraine: concepts and essential characteristics]. Visnyk LDFA - Herald of LSAF, 21, 208218 [in Ukrainian].

2. Barannyk, L.B. (2014). Finansove zabezpechennia systemy sotsialnoho zakhystu naselennia: teoretychnyi aspekt [The financial support of people's social protection system: the theoretical aspect]. Visnyk DDFA - Herald of DSAF, 1, 8-15 [in Ukrainian].

3. Savchenko, N.H. (2010). Finansovyi mekhanizm sotsialnoho zakhystu naselennia Ukrainy [The financial mechanism of people's social protection system in Ukraine]. Thesis 08.00.08. Kyiv: Kyiv national university of trade and economics [in Ukrainian].

4. Babych, L.M. \& Vasechko, L.I. (2009). Optymizatsiina model finansovoho mekhanizmu sotsialnoho strakhuvannia Ukrainy [Optimization model of financial mechanism of social insurance in Ukraine]. Aktualni problemy ekonomiky - Actual problems of the economy, 1, 158-170 [in Ukrainian].
5. Vasechko, L.I. (2010). Finansovyi mekhanizm sotsialnoho strakhuvannia $v$ Ukraini [The financial mechanism of social insurance in Ukraine]. Thesis 08.00.08. Irpin [in Ukrainian].

6. Horianska, S.V. (2001). Finansove zabezpechennia sotsialnoho zakhystu naselennia [The financial support of people's social protection]. Finansy Ukrainy - Finance of Ukraine, 6, 87-95 [in Ukrainian].

7. Dyn, I.M. (2010). Finansovyi mekhanizm funktsionuvannia pensiinykh fondiv $v$ Ukraini [The financial mechanism of functioning of pension funds in Ukraine]. Thesis 08.00.08. Lviv: IRD NAN Ukrainy [in Ukrainian].

8. Klividenko, L.M. (2006). Finansove zabezpechennia sotsialnoho zakhystu Ukrainy [The financial support of people's social protection]. Ternopil: TNEU [in Ukrainian].

Стаття надійшла до редакції 28.04.2017. 